\title{
Current issues and perspectives in prenatal nutrition
}

This article was published in the following Dove Press journal:

Research and Reports in Neonatology

25 May $201 \mathrm{I}$

Number of times this article has been viewed

\author{
John C Morrison' \\ John Elliott ${ }^{2}$ \\ Robert A Knuppel ${ }^{3}$ \\ Baha Sibai ${ }^{4}$ \\ Michael W Pill ${ }^{5}$ \\ 'Department of Obstetrics and \\ Gynecology, University of Mississippi \\ Medical Center, Jackson, MS, USA; \\ ${ }^{2}$ Saddleback Memorial Medical Center, \\ Women's Hospital, Laguna Hills, \\ CA, USA; ${ }^{3}$ DuBois Regional Medical \\ Center, DuBois, PA, USA; ${ }^{4}$ University \\ of Cincinnati College of Medicine, \\ Cincinnati, OH, USA; ${ }^{5}$ Gemini \\ Healthcare, Westbrook, CT, USA
}

\begin{abstract}
The typical American diet, characterized by energy-dense foods rich in starches, sugars, and saturated fats, and low in fruits and vegetables, is relatively unhealthy and is associated with nutritional deficiencies. Suboptimal diets for pregnant women have been associated with serious maternal medical complications (eg, iron deficiency anemia, high blood pressure, gestational diabetes, and morning sickness), as well as an increased risk of intrauterine growth restriction, birth defects, developmental delays after birth, and future chronic health problems, (eg, heart disease, type 2 diabetes, high blood pressure, and high cholesterol) during childhood, as well as later in life. Folic acid deficiency is one of the most common problems among pregnant women, and supplementation with folic acid during pregnancy has been reported to decrease the occurrence and recurrence of fetal neural tube defects. Folate supplementation beginning preconception, along with a multivitamin, at least 12 weeks prior to conception is recommended to achieve maximal risk reduction. The reported benefits of supplementing docosahexaenoic acid, an unsaturated omega-3 essential fatty acid, during pregnancy include promoting proper neurodevelopment in fetuses and infants that extends into childhood. Pregnancy is also associated with an increased susceptibility to oxidative stress, resulting from the imbalance between oxygen free radicals and the essential antioxidants that maintain homeostasis. Associated complications include preeclampsia, preterm labor, and intrauterine growth restriction. There is not enough evidence to support routine use of antioxidants, such as vitamins $\mathrm{C}$ and $\mathrm{E}$ during pregnancy, but coenzyme Q10 and lycopene are additional antioxidants under study and are yielding promising results by decreasing the occurrence of maternal complications.
\end{abstract}

Keywords: prenatal nutrition, oxidative stress, coenzyme Q10, lycopene

\section{Introduction}

The typical American diet, characterized by energy-dense foods rich in starches, sugars, and saturated fats and low in fruits and vegetables, is relatively unhealthy and associated with multiple nutritional deficiencies. ${ }^{1,2}$ Good nutrition is particularly important for pregnant women, because pregnancy places extra nutritional demands on the mother to satisfy the needs of the growing fetus. ${ }^{1,3}$ The ability of many pregnant women to consume an optimal diet throughout pregnancy is also limited by factors such as fatigue, nausea, food cravings, busy lifestyles and, for some, lack of knowledge in this area. ${ }^{2}$

Suboptimal prenatal diets have been associated with serious maternal medical complications, such as iron deficiency anemia, high blood pressure, gestational diabetes, and morning sickness. ${ }^{2}$ Moreover, deficient prenatal diets have been reported to lead to an increased risk of intrauterine growth restriction, birth defects,
Profespondence: John C Morrison and Pediatrics, Department of Obstetrics and Gynecology, University of Mississippi Medical Center, Jackson, MS 39216, USA Tel +l 60I 6682024

Email jmorrison@umc.edu which permits unrestricted noncommercial use, provided the original work is properly cited. 
and developmental delays after birth, as well as future chronic health problems (ie, subsequent heart disease, type 2 diabetes, high blood pressure, and high cholesterol during childhood, as well as later in life)., ${ }^{2,4}$ While the risk of complications is higher among women whose diets are deficient in micronutrients, even a healthy and carefully planned diet may not be sufficient to meet the increased demands of pregnancy. ${ }^{2}$ It has been estimated that up to $30 \%$ of pregnant women suffer from a vitamin deficiency. ${ }^{4}$ Therefore, many experts in pregnancy nutrition recommend prenatal nutritional supplements to ensure optimal infant and maternal outcomes. ${ }^{2-5}$

To help prevent pregnancy-related complications associated with diets low in nutritional value, the American College of Obstetricians and Gynecologists has recommended that pregnant women have appropriate weight gain, consume a variety of foods in accordance with the Food Guide Pyramid during pregnancy, have appropriate and timely vitamin and mineral supplementation added to the diet, and that alcohol, tobacco, and other harmful substances be avoided. ${ }^{3}$ Because approximately $50 \%$ of pregnancies are unplanned, and women's health status may not be optimal when they conceive, women in the reproductive age group should be advised about the benefits of folic acid in addition to a multivitamin supplement during wellness visits, especially if pregnancy is contemplated. ${ }^{6}$

Based on our review of the literature and clinical practice experience, we provide our perspective on two key nutrients that contribute to maternal and fetal health (folate and docosahexaenoic acid [DHA] supplementation), as well as discuss the importance of oxidative stress in pregnancy and current research with antioxidants that may have a role in reducing its sequelae. To the extent that there are some relevant differences in diet and nutritional guidance among countries, the perspective for the current discussion is prenatal diet and nutritional supplementation in the US.

\section{Current prenatal nutrition supplements}

Prenatal nutrition supplements are formulated with a wide variety of micronutrients; most include vitamins, essential fatty acids, and minerals. Actual combinations of micronutrients may vary from one supplement to another, depending upon the intended nutritional focus, eg, a higher amount of iron for women who are prone to iron deficiency anemia. Many commercially available formulations of prenatal nutrition supplements include vitamins C, B1, B2, B12, E, D3, folic acid, copper, zinc, iron, magnesium, docusate,
DHA, linolenic acid, eicosapentaenoic acid, calcium, and pantothenic acid (Table 1).

\section{Importance of folic acid: Metafolin ${ }^{\circledR}$ versus folic acid}

Adequate intake of folic acid is necessary during pregnancy and confers benefits for both mother and fetus. Folic acid is a water-soluble B vitamin that is needed for efficient red blood cell production and metabolism of homocysteine. ${ }^{4}$ This is an essential vitamin during pregnancy and also plays a vital role in DNA synthesis and methylation (gene silencing), contributing to regulation of gene expression. ${ }^{4}$ Folic acid deficiency is one of the most common problems amongst pregnant women. Supplementation with folic acid during pregnancy has been reported to decrease the occurrence and recurrence of fetal neural tube defects; a preventive role for folic acid has also been suggested for other congenital anomalies, such as oral clefts and congenital heart disease, although the clinical evidence for this role remains somewhat equivocal. ${ }^{7-9}$ Currently available prenatal nutrition supplements generally contain $1 \mathrm{mg}$ of folic acid. Supplemental folic acid in excess of $1 \mathrm{mg}$ can prevent some of the signs and symptoms of vitamin B12 deficiency from being expressed, including megaloblastic anemia, but it will not halt the progression of associated severe neuropathies. ${ }^{10}$ Thus, supplements that contain folic acid at levels of $1 \mathrm{mg}$ or greater are dispensed via prescription in the US. In addition, concerns were raised in the late 1960s, suggesting that folic acid in large amounts might counteract the antiseizure effects of antiepileptic drugs and increase the seizure frequency in some children. ${ }^{11}$ We are unaware of published reports of pregnant women consuming too much folic acid leading to toxicities.

A recent question has been raised as to what is the best formulation of folic acid for pregnant women? Some suggest that the combination of L-methylfolate (as Metafolin ${ }^{\circledR}$ $600 \mu \mathrm{g}$, folic acid USP $400 \mu \mathrm{g}$ ) is better than the standard $1 \mathrm{mg}$ of folic acid. Theoretically, Metafolin results in higher folate levels and, in the rare case where the fetus is deficient (homozygous) in methylenetetrahydrofolate reductase, it seems better incorporated into fetal tissue. Lamers et al measured red cell folate concentrations in 136 nonpregnant women who received either $400 \mu \mathrm{g}$ folic acid, $416 \mu \mathrm{g}$ Metafolin, $208 \mu \mathrm{g}$ Metafolin, or placebo daily for 24 weeks (Table 2). During the first four weeks of treatment, folic acid was more rapidly absorbed than Metafolin. ${ }^{12}$ At eight weeks, both compounds yielded red cell folate levels above the threshold level ( $906 \mathrm{nmol} / \mathrm{L}$ as determined by Daly et $\mathrm{al}^{13}$ ) for open neural tube defects (at levels of $906 \mathrm{nmol} / \mathrm{L}$ or greater, 
no neural tube defects should occur). At 16 weeks, Metafolin yielded a red cell folate concentration that was $8 \%$ higher than folic acid. However, since all subjects were above the $906 \mathrm{nmol} / \mathrm{L}$ cutoff, the $8 \%$ increase would not be clinically important in our opinion. The upper limit of red cell folate levels achieved at 24 weeks was approximately $1400 \mathrm{nmol} / \mathrm{L}$ with Metafolin $416 \mu \mathrm{g} /$ day, $1300 \mathrm{nmol} / \mathrm{L}$ with folic acid $400 \mu \mathrm{g} /$ day, and $1100 \mathrm{nmol} / \mathrm{L}$ with Metafolin $208 \mu \mathrm{g} /$ day. Similarly, Venn et al studied red blood cell folate concentrations every four weeks over a 24-week period in 104 nonpregnant women (Table 2). ${ }^{14}$ The folic acid preparations in this study used lower doses of both Metafolin and folic acid, and both products resulted in levels $>900 \mathrm{nmol} / \mathrm{L}$ by four weeks The upper limit of red cell folate levels achieved at 24 weeks was approximately $1050 \mathrm{nmol} / \mathrm{L}$ with Metafolin $113 \mu \mathrm{g} /$ day and $1150 \mathrm{nmol} / \mathrm{L}$ with folic acid $100 \mu \mathrm{g} /$ day.

Based on our review of the literature, there does not appear to be a clinically compelling reason to use the more expensive Metafolin product. We acknowledge the theoretical concern regarding the high serum folate levels that might occur with the additional $1 \mathrm{mg}$ of folic acid in prenatal vitamins in areas where folate fortification of food is common. However, to our knowledge, there have been no human data or animal data published to suggest that high serum folate levels have been associated with adverse effects, and, as noted in the American Academy of Pediatrics statement on the use of folic acid for the prevention of neural tube defects, approximately a quarter of all women have consumed folic acid for many years and extensively during later pregnancy without apparent adverse effects. ${ }^{15}$ Regarding the potential for higher doses of folic acid to mask megaloblastic anemia, but not neuropathies associated with vitamin B12 deficiency, pernicious anemia rarely occurs before 50 years of age, so is likely to be rare among women consuming folic acid during the reproductive years. ${ }^{15}$ In view of these data, the health care provider should prescribe the folate product with which he or she is most comfortable.

As it may take up to 12 weeks for plasma folate and red blood cell folate concentrations to reach the threshold level needed to minimize the risk for neural tube defects, folate supplementation preconception, along with a multivitamin, at least 12 weeks prior to conception is recommended to achieve maximal risk reduction. ${ }^{6,12}$

\section{How much DHA is needed?}

DHA is an unsaturated omega-3 essential fatty acid found mainly in fish and marine plants. The benefits of DHA supplementation during pregnancy have been reported in randomized clinical trials, and several observational studies have reported a correlation between higher intrauterine DHA exposure and a number of positive developmental outcomes, including promoting proper neurodevelopment in fetuses and infants that extends into childhood. ${ }^{16-18}$ However, the results are far from conclusive because other studies have reported no effects on neurodevelopment. ${ }^{19,20}$ A number of studies have reported positive effects on fetal growth that continues after birth. ${ }^{19,21,22}$ Results from the DOMINO trial ${ }^{19}$ (DHA to Optimize Mother Infant Outcome) indicated that women who had supplemental DHA administered from week 21 onwards had a statistically significant reduction in preterm births $(P=0.03)$ and birth of low weight infants $(P=0.03)$ when compared with the control group administered matched vegetable oil capsules (Table 2). The trial further reported an overall decrease in neonatal intensive care admissions $(P=0.04)$. A study by Stein et al reported that maternal DHA supplementation during the second half of gestation may enhance growth through 18 months for children born to primigravid women (Table 2). ${ }^{21}$

While there is no standard recommendation for daily intake of DHA across the various professional agencies, organizations and societies, a general range does exist. A consensus statement from a workshop sponsored by the National Institutes of Health and the International Society for the Study of Fatty Acids and Lipids recommends a DHA intake of $300 \mathrm{mg} /$ day for pregnant and nursing women. ${ }^{23}$ Other consensus groups have recommended at least $200 \mathrm{mg} /$ day as the optimal dose. ${ }^{24,25}$

A variety of DHA supplements are available, but there has been some debate about the equivalence of supplement-derived sources and natural food sources. ${ }^{26}$ This was examined in a study that compared the nutritional availability of DHA from algal oil capsules with that from assayed cooked salmon in 32 healthy men and women. Participants consumed either $600 \mathrm{mg}$ DHA from the algal oil capsules or cooked salmon for 14 days. Both interventions resulted in equivalent amounts of DHA delivered to plasma phospholipids and erythrocytes. However, in a study using DHA derived from fish oil capsules, daily intake of cooked salmon resulted in considerably higher levels of DHA than the supplement. ${ }^{27}$ The Institute of Medicine guidance for daily intake of fish during pregnancy results in consumption of about $200-300 \mathrm{mg} /$ day of DHA. ${ }^{16}$ However, the availability of bioequivalent supplements is important because it is highly unlikely that all women will consume the recommended amount of fish during pregnancy, particularly in view of the guidance that only 
Table I Prenatal micronutrient supplement comparison ${ }^{89-101}$

\begin{tabular}{|c|c|c|c|c|c|c|}
\hline & $\begin{array}{l}\text { RDA } \\
\text { (FNB 2009) }\end{array}$ & PreQue $10^{\prime}$ & $\begin{array}{l}\text { OB complete } \\
400^{2}\end{array}$ & PreNexa $^{3}$ & $\begin{array}{l}\text { Prenate } \\
\text { DHA }^{4}\end{array}$ & $\begin{array}{l}\text { Vitafol } \\
\text { OB-DHA }\end{array}$ \\
\hline Administration & - & $\begin{array}{l}2 \text { tablets once } \\
\text { daily or I tablet } \\
\text { twice daily }\end{array}$ & Once daily & Once daily & Once daily & $\begin{array}{l}2 \text { pills once } \\
\text { daily }\end{array}$ \\
\hline \multicolumn{7}{|l|}{ Antioxidants } \\
\hline Coenzyme QI0 & 0 & $100 \mathrm{mg}$ & 0 & 0 & 0 & 0 \\
\hline Lycopene & 0 & $10 \mathrm{mg}$ & 0 & 0 & 0 & 0 \\
\hline \multicolumn{7}{|l|}{ Vitamins } \\
\hline $\begin{array}{l}\text { Vitamin A } \\
\text { (beta-carotene) }\end{array}$ & $0.75-0.77 \mathrm{mg}^{\mathrm{a}}$ & $2500 \mathrm{IU}$ & 0 & 0 & 0 & $2700 \mathrm{IU}$ \\
\hline $\begin{array}{l}\text { Vitamin } B_{1} \\
\text { (thiamine mononitrate) }\end{array}$ & $1.4 \mathrm{mg}$ & $2 \mathrm{mg}$ & $2 \mathrm{mg}$ & 0 & 0 & $1.6 \mathrm{mg}$ \\
\hline Vitamin $B_{2}$ (riboflavin) & $1.4 \mathrm{mg}$ & $3.4 \mathrm{mg}$ & $3.4 \mathrm{mg}$ & 0 & 0 & $1.8 \mathrm{mg}$ \\
\hline $\begin{array}{l}\text { Vitamin } \mathrm{B}_{6} \\
\text { (pyridoxine } \mathrm{HCl} \text { ) }\end{array}$ & $1.9 \mathrm{mg}$ & 0 & $25 \mathrm{mg}$ & $25 \mathrm{mg}$ & $25 \mathrm{mg}$ & $2.5 \mathrm{mg}$ \\
\hline $\begin{array}{l}\text { Vitamin } B_{12} \\
\text { (cyanocobalamin) }\end{array}$ & $26 \mu g$ & $2 \mu \mathrm{g}$ & $26 \mu g$ & 0 & $12 \mu \mathrm{g}$ & $12 \mu \mathrm{g}$ \\
\hline Folate/folic acid & $0.6 \mathrm{mg}$ & I mg & $1.2 \mathrm{mg}$ & $1.2 \mathrm{mg}$ & $1.0 \mathrm{mg}$ & $1.0 \mathrm{mg}$ \\
\hline $\begin{array}{l}\text { Vitamin } \mathrm{D}_{3} \\
\text { (cholecalciferol) }\end{array}$ & $200 \mathrm{IU}^{\mathrm{b}}$ & $240 \mathrm{IU}$ & $800 \mathrm{IU}$ & I70 IU & $200 \mathrm{IU}$ & $400 \mathrm{IU}$ \\
\hline Vitamin C & $80-85 \mathrm{mg}^{\mathrm{c}}$ & $60 \mathrm{mg}$ & $\begin{array}{l}100 \mathrm{mg} \\
\text { (as ascorbic acid } \\
\text { with calcium ascorbate } \\
\text { and calcium } \\
\text { threonate) }\end{array}$ & $25 \mathrm{mg}$ & $85 \mathrm{mg}$ & $70 \mathrm{mg}$ \\
\hline $\begin{array}{l}\text { Vitamin E } \\
\text { (d-alpha tocopherol) }\end{array}$ & $22.35 \mathrm{IU}$ & $30 \mathrm{IU}$ & $\begin{array}{l}30 \mathrm{IU} \text { (as hypersorb } \\
\text { vitamin } \mathrm{E})\end{array}$ & $30 \mathrm{IU}$ & $10 \mathrm{IU}$ & $30 \mathrm{IU}$ \\
\hline Niacin (niacinamide) & $18 \mathrm{mg}$ & 0 & $10 \mathrm{mg}$ & 0 & 0 & $18 \mathrm{mg}$ \\
\hline \multicolumn{7}{|l|}{ Minerals } \\
\hline Copper & $\mathrm{I} \mathrm{mg}$ & $2 \mathrm{mg}$ & $\mathrm{I} \mathrm{mg}$ & 0 & 0 & $2 \mathrm{mg}$ \\
\hline Zinc (zinc oxide) & $11-12 \mathrm{mg}^{\mathrm{d}}$ & $25 \mathrm{mg}$ & $25 \mathrm{mg}$ & 0 & 0 & $25 \mathrm{mg}$ \\
\hline Iron & $27 \mathrm{mg}$ & $30 \mathrm{mg}$ & $\begin{array}{l}40 \mathrm{mg} \\
\text { (as Ferronyl } \\
\text { and Ferrochel }{ }^{\circledR} \text { ) }\end{array}$ & $30 \mathrm{mg}$ & $27 \mathrm{mg}$ & $65 \mathrm{mg}$ \\
\hline Calcium & $1000-1300 \mathrm{mg}^{\mathrm{e}}$ & 0 & 0 & $160 \mathrm{mg}$ & $140 \mathrm{mg}$ & $100 \mathrm{mg}$ \\
\hline $\begin{array}{l}\text { Magnesium } \\
\text { (magnesium oxide) }\end{array}$ & $350-400 \mathrm{mg}^{f}$ & $20 \mathrm{mg}$ & 0 & 0 & $45 \mathrm{mg}$ & $25 \mathrm{mg}$ \\
\hline $\begin{array}{l}\text { Selenium } \\
\text { (as sodium selenate) }\end{array}$ & 0 & $15 \mu g$ & 0 & 0 & 0 & 0 \\
\hline \multicolumn{7}{|l|}{ Purified fish oil } \\
\hline $\begin{array}{l}\text { Docosahexaenoic acid } \\
\text { Other omegas }\end{array}$ & NA & $100 \mathrm{mg}$ & $\geq 320 \mathrm{mg}$ & $265 \mathrm{mg}$ & $300 \mathrm{mg}$ & $250 \mathrm{mg}$ \\
\hline \multicolumn{7}{|l|}{ Other micronutrients } \\
\hline $\begin{array}{l}\text { lodine } \\
\text { (potassium iodide) }\end{array}$ & $0.22 \mathrm{mg}$ & 0 & 0 & 0 & 0 & 0 \\
\hline $\begin{array}{l}\text { Choline } \\
\text { (choline bitartrate) }\end{array}$ & $450 \mathrm{mg}$ & 0 & 0 & 0 & 0 & 0 \\
\hline
\end{tabular}




\begin{tabular}{|c|c|c|c|c|c|c|c|}
\hline $\begin{array}{l}\text { Citranatal } \\
\text { Assure }^{6}\end{array}$ & $\begin{array}{l}\text { Gesticare } \\
\text { DHA }^{7}\end{array}$ & $\begin{array}{l}\text { OB Complete } \\
\text { One }^{8}\end{array}$ & $\begin{array}{l}\text { Prenate } \\
\text { Essentia }^{9}\end{array}$ & $\begin{array}{l}\text { Citranatal } \\
\text { Harmony }^{10}\end{array}$ & $\begin{array}{l}\text { Prefera OB } \\
\text { Onell }^{\prime \prime}\end{array}$ & $\begin{array}{l}\text { Neevo } \\
\text { DHA }^{12}\end{array}$ & $\begin{array}{l}\text { Concept } \\
\text { DHA }^{13}\end{array}$ \\
\hline $\begin{array}{l}2 \text { pills } \\
\text { once daily }\end{array}$ & $\begin{array}{l}2 \text { pills } \\
\text { once daily }\end{array}$ & Once daily & Once daily & Once daily & Once daily & Once daily & Once daily \\
\hline 0 & 0 & 0 & 0 & 0 & 0 & 0 & 0 \\
\hline 0 & 0 & 0 & 0 & 0 & 0 & 0 & 0 \\
\hline 0 & 0 & 0 & 0 & 0 & 0 & 0 & 0 \\
\hline $3 \mathrm{mg}$ & $3 \mathrm{mg}$ & $2 \mathrm{mg}$ & 0 & 0 & 0 & 0 & $2 \mathrm{mg}$ \\
\hline $3.4 \mathrm{mg}$ & $3 \mathrm{mg}$ & $4 \mathrm{mg}$ & 0 & 0 & 0 & 0 & $3 \mathrm{mg}$ \\
\hline $25 \mathrm{mg}$ & $50 \mathrm{mg}$ & $30 \mathrm{mg}$ & $25 \mathrm{mg}$ & $25 \mathrm{mg}$ & $50 \mathrm{mg}$ & $25 \mathrm{mg}$ & $25 \mathrm{mg}$ \\
\hline 0 & $8 \mu \mathrm{g}$ & $50 \mu \mathrm{g}$ & $12 \mu \mathrm{g}$ & 0 & $12 \mu \mathrm{g}$ & $50 \mu g$ & $12.5 \mu \mathrm{g}$ \\
\hline $1.0 \mathrm{mg}$ & $1.0 \mathrm{mg}$ & $1.0 \mathrm{mg}$ & $1.0 \mathrm{mg}$ & $1.0 \mathrm{mg}$ & $1.0 \mathrm{mg}$ & 1.0 mgm & 1.0 \\
\hline $400 \mathrm{IU}$ & $410 \mathrm{IU}$ & I200 IU & $200 \mathrm{IU}$ & $400 \mathrm{IU}$ & $400 \mathrm{IU}$ & $400 \mathrm{IU}$ & 0 \\
\hline $120 \mathrm{mg}$ & $120 \mathrm{mg}$ & $70 \mathrm{mg}$ & $85 \mathrm{mg}$ & 0 & $25 \mathrm{mg}$ & $40 \mathrm{mg}$ & $25 \mathrm{mg}$ \\
\hline $30 \mathrm{IU}$ & $30 \mathrm{IU}$ & $30 \mathrm{IU}$ & $\mathrm{I} 0 \mathrm{IU}$ & $30 \mathrm{IU}$ & $\mathrm{I} 0 \mathrm{IU}$ & $30 \mathrm{IU}$ & 0 \\
\hline $20 \mathrm{mg}$ & $20 \mathrm{mg}$ & $10 \mathrm{mg}$ & 0 & 0 & $17 \mathrm{mg}$ & 0 & $1.8 \mathrm{mg}$ \\
\hline $2 \mathrm{mg}$ & 0 & $\mathrm{l}$ mg & 0 & 0 & 0 & 0 & $2 \mathrm{mg}$ \\
\hline $25 \mathrm{mg}$ & $15 \mathrm{mg}$ & $15 \mathrm{mg}$ & 0 & 0 & 15 mg & 0 & 10 mg \\
\hline $35 \mathrm{mg}$ & $27 \mathrm{mg}$ & $\begin{array}{l}40 \text { mg (Ferronyl) } \\
10 \text { mg sumalate } \\
\text { (elemental iron) }\end{array}$ & $\begin{array}{l}28 \mathrm{mg} \text { (ferrous } \\
\text { fumarate) }\end{array}$ & $\begin{array}{l}27 \mathrm{mg} \text { (carbonyl } \\
\text { iron) }\end{array}$ & $\begin{array}{l}22 \mathrm{mg} \\
\text { polysaccharide } \\
\text { iron complex } \\
6 \mathrm{mg} \text { as } \\
\text { (heme iron } \\
\text { polypeptide) }\end{array}$ & $\begin{array}{l}27 \mathrm{mg} \\
\text { (ferrous } \\
\text { fumarate) }\end{array}$ & $\begin{array}{l}17.5 \mathrm{mg} \\
\text { (ferrous fumarate) } \\
\text { I7.5 mg } \\
\text { polysaccharide } \\
\text { iron complex }\end{array}$ \\
\hline $125 \mathrm{mg}$ & $200 \mathrm{mg}$ & $\begin{array}{l}25 \mathrm{mg}\left(\mathrm{DimaCal}{ }^{\circledR}\right) \\
\text { and } 25 \mathrm{mg} \text { calcium } \\
\text { carbonate }\end{array}$ & $140 \mathrm{mg}$ & $100 \mathrm{mg}$ & 0 & $75 \mathrm{mg}$ & 0 \\
\hline 0 & 0 & $25 \mathrm{mg}$ & $45 \mathrm{mg}$ & 0 & 0 & 0 & $5 \mathrm{mg}$ \\
\hline 0 & 0 & 0 & 0 & 0 & 0 & 0 & 0 \\
\hline $300 \mathrm{mg}$ & $250 \mathrm{mg}$ & $\begin{array}{l}\geq 300 \mathrm{mg} \\
\geq 40 \mathrm{mg}\end{array}$ & $\begin{array}{l}300 \mathrm{mg} \\
40 \mathrm{mg}\end{array}$ & $250 \mathrm{mg}$ & $200 \mathrm{mg}$ & $250 \mathrm{mg}$ & $\begin{array}{l}156 \mathrm{mg} \\
39 \mathrm{mg}\end{array}$ \\
\hline $150 \mu \mathrm{g}$ & $150 \mu g$ & $150 \mu \mathrm{g}$ & $150 \mu g$ & 0 & $175 \mu \mathrm{g}$ & 0 & 0 \\
\hline 0 & $55 \mathrm{mg}$ & 0 & 0 & 0 & 0 & 0 & 0 \\
\hline
\end{tabular}

Notes: ${ }^{2} 0.75 \mathrm{mg} /$ day for women $14-18$ years and $0.77 \mathrm{mg} /$ day for women $19-50$ years; ${ }^{\mathrm{A}} \mathrm{Al}$, daily adequate intake for pregnant women; $80 \mathrm{mg} / \mathrm{day}$ for women $14-18$ years and $85 \mathrm{mg} /$ day for women $19-50$ years; ${ }^{\mathrm{d}} \mathrm{l} \mathrm{mg} /$ day for women $19-50$ years and $12 \mathrm{mg} /$ day for women $14-18$ years; ${ }^{\mathrm{e}} \mathrm{Al}$, daily adequate intake for pregnant women; 1000 for women 19-50 years and $1300 \mathrm{mg}$ for women $14-18$ years; $350 \mathrm{mg} /$ day for women $19-30$ years, $360 \mathrm{mg} /$ day for women $31-50$ years, and $400 \mathrm{mg} / \mathrm{day}$ for women 14-18 years.

Abbreviations: FNB, Food and Nutrition Board; RDA, recommended dietary allowance per day for pregnant women. 
Table 2 Selected clinical outcome studies of prenatal supplements

\begin{tabular}{|c|c|c|}
\hline Study & Subjects (n)/duration/design & Intervention \\
\hline Lamers et al ${ }^{12}$ & $\begin{array}{l}\text { Nonpregnant women } 18-35 \text { years }(n=136) \\
24 \text { weeks } \\
\text { DB, R, PC }\end{array}$ & $\begin{array}{l}\text { FA } 400 \mu g \text { or } \\
\text { [6S]-5-MTHF* } 416 \mu g \text { or } \\
\text { [6S]-5-MTHF } 416 \mu \mathrm{g} \text { or } \\
\text { placebo }\end{array}$ \\
\hline Venn et $\mathrm{al}^{14}$ & $\begin{array}{l}\text { Nonpregnant women } 18-49 \text { years }(n=104) \\
24 \text { weeks } \\
\text { DB, R, PC }\end{array}$ & $\begin{array}{l}\text { FA } 100 \mu \mathrm{g} \text { or } \\
{[6 \mathrm{~S}]-5-\mathrm{MTHF}^{*} 113 \mu \mathrm{g} \text { or }} \\
\text { placebo }\end{array}$ \\
\hline
\end{tabular}

Makrides et al $^{19} \quad$ Pregnant women less than 21 weeks gestation $(n=2399)$

Follow-up of children $(n=726)$

Treatment received from study entry until delivery

$\mathrm{DB}, \mathrm{R}, \mathrm{PC}$

Stein et $\mathrm{al}^{21}$

Roberts et $\mathrm{al}^{59}$

Spinnato et $\mathrm{al}^{60}$

Pregnant women at gestational week 12-19 with chronic hypertension or prior history of pre-eclampsia $(n=739)$

Treatment from study entry until delivery or diagnosis of pre-eclampsia

DB, R, PC

Poston et $\mathrm{al}^{61}$

Pregnant women at increased risk for pre-eclampsia and at gestational week |4-2| $(n=24 \mid 0)$

Treatment from study entry until delivery DB, R, PC
DHA fish oil 800 mg/day or placebo

Algal DHA 400 mg/day or placebo

Vitamin C $1000 \mathrm{mg}$ and vitamin E 400 IU or placebo

Vitamin C $1000 \mathrm{mg}$ and vitamin E 400 IU or placebo

Vitamin C $1000 \mathrm{mg}$ and vitamin E 400 IU or placebo

\section{Outcome}

Red cell folate levels:

- 4 weeks - FA more rapidly absorbed

- 8 weeks - both compounds yield levels above "safe" threshold

- 16 weeks - [6S]-5-MTHF yields concentration $8 \%$ higher than FA

- No difference in slopes between active treatment groups in either plasma folate or red cell folate levels

- At 24 weeks, estimated mean increase in red cell folate levels:

FA: $275 \mathrm{nmol} / \mathrm{L}$

[6S]-5-MTHF: $25 \mathrm{I} \mathrm{nmol/L}$

- No difference between groups in mean cognitive scores or mean language scores ${ }^{102}$

- Very preterm births (<34 weeks): I.09\% DHA vs $2.25 \%$ placebo (adjusted RR, 0.49; $95 \% \mathrm{Cl} 0.25-0.94, P=0.03$ )

- Post-term births requiring induction or cesarean delivery: 17.6\% DHA vs $13.7 \%$ placebo (adjusted RR, I.28; Cl I.06-I.54, $P=0.0 \mathrm{I}$ )

- Low birth weight infants: $3.41 \%$ DHA vs $5.27 \%$ placebo (adjusted RR $0.65, \mathrm{Cl}$ $0.44-0.96 ; P=0.03$ )

- At 18 months, differences in length, weight, and head circumference were not significantly different between groups in total population

- Among offspring of primigravid women: length at 18 months increased by $0.72 \mathrm{~cm}$ vs placebo $(95 \% \mathrm{Cl} 0.1 \mathrm{I}-\mathrm{I} .33)$

- No significant difference between treatment group and placebo in rates of pre-eclampsia (7.2\% vs $6.7 \%$, respectively; RR I.07, Cl 0.93-I.24) or in rates of other complications (eg, severe pregnancy-related hypertension, elevated liver enzymes, thrombocytopenia, elevated serum creatinine, eclamptic seizure, fetal growth restriction, perinatal death)

- No significant difference between treatment group and placebo in rate of pre-eclampsia (I3.8\% vs $15.6 \%$, adjusted RR 0.87 , $\mathrm{Cl} 0.6 \mathrm{I}-\mathrm{I} .25)$, or in mean gestational age at delivery, rates of perinatal mortality, preterm delivery, low birth weight, or other complications

- No significant difference between treatment group and placebo in rate of pre-eclampsia (15\% vs $16 \%$, adjusted RR 0.97 ,

Cl 0.80-I.I7)

- More low birth weight infants born in antioxidant treatment group vs placebo (28\% vs $24 \%$, RR I. I5, Cl I.02-1.30)

- No difference between groups in small size for gestational age 
Table 2 (Continued)

\begin{tabular}{|c|c|c|c|}
\hline Study & Subjects (n)/duration/design & Intervention & Outcome \\
\hline Teran et $a^{67}$ & $\begin{array}{l}\text { Primigravid pregnant women at increased } \\
\text { risk for pre-eclampsia, } 20 \text { years old or } \\
\text { younger, and at gestational week } 16-20 \\
(n=235) \\
\text { Treatment from study entry until delivery } \\
\text { DB, R, PC }\end{array}$ & $\begin{array}{l}\text { Coenzyme Q10 } 200 \text { mg/day or } \\
\text { placebo }\end{array}$ & $\begin{array}{l}\text { - Pre-eclampsia } 14.4 \% \text { vs } 25.5 \% \text { in coenzyme } \\
\text { QI0 and placebo groups, respectively } \\
\text { (RR 0.56, CI } 0.33-0.96 ; P=0.035 \text { ) } \\
\text { - Incidence of low birth weight similar } \\
\text { between groups ( } 10 \% \text { vs } 12.3 \% \text { for coenzyme } \\
\text { QI0 and placebo groups, respectively) } \\
\text { - No perinatal mortality }\end{array}$ \\
\hline Sharma et $\mathrm{al}^{74}$ & $\begin{array}{l}\text { Primigravid women at gestational } \\
\text { week I6-20 }(n=25 I) \\
\text { Treatment from study entry until delivery } \\
\text { DB, R, PC }\end{array}$ & $\begin{array}{l}\text { Lycopene } 2 \mathrm{mg} \text { twice daily or } \\
\text { placebo }\end{array}$ & $\begin{array}{l}\text { - Pre-eclampsia } 8.6 \% \text { vs } 17.7 \% \text { in lycopene and } \\
\text { placebo groups, respectively }(P=0.043) \\
\text { - Mean DBP } 86.7 \mathrm{mmHg} \text { vs } 92.2 \mathrm{mmHg} \\
\text { in lycopene and placebo groups, } \\
\text { respectively }(P=0.0 \mathrm{I} 2) \\
\text { - Mean fetal weight } 275 \mathrm{I} \text { g vs } 2657 \mathrm{~g} \\
\text { in lycopene and placebo groups, respectively } \\
(P=0.049) \\
\text { - Incidence of intrauterine growth retardation } \\
\text { I } 2 \% \text { vs } 23.7 \% \text { in lycopene and placebo } \\
\text { groups, respectively }(P=0.033)\end{array}$ \\
\hline Kramer et $\mathrm{al}^{75}$ & $\begin{array}{l}\text { Frozen plasma samples from pregnant } \\
\text { women taken at } 24-26 \text { weeks' gestation: } \\
\text { spontaneous preterm births }(n=207) \\
\text { and term delivery controls }(n=443) \\
\text { Case-control nested study }\end{array}$ & No treatment & $\begin{array}{l}\text { - High (above median) plasma concentrations } \\
\text { of lycopene were associated with reduced } \\
\text { risk of spontaneous preterm birth: } \\
\text { - Median-based: adjusted OR } 0.6 \\
\text { ( } 95 \% \mathrm{Cl} 0.4-0.9) \\
\text { - Dose-response effects across quartiles }\end{array}$ \\
\hline Banerjee et $\mathrm{al}^{86}$ & $\begin{array}{l}\text { Primigravid women at gestational } \\
\text { week I2-20 weeks }(n=I 59) \\
\text { Treatment from study entry until delivery } \\
\text { R, DB, PC }\end{array}$ & $\begin{array}{l}\text { Lycopene } 2 \mathrm{mg} / \mathrm{day} \\
\text { or placebo }\end{array}$ & $\begin{array}{l}\text { - No difference between treatment groups } \\
\text { in pre-eclampsia } \\
\text { - Preterm labor: } 10.39 \% \text { vs I.22\% in lycopene } \\
\text { and placebo groups, respectively }(P=0.02) \\
\text { - Low birthweight }(<2.5 \mathrm{~kg}) \text { infants: } 22.08 \% \\
\text { vs } 9.76 \% \text { in lycopene and placebo groups, } \\
\text { respectively }(P=0.05)\end{array}$ \\
\hline
\end{tabular}

Note: * Metafolin ${ }^{\circledR}$.

Abbreviations: DB, double-blind; R, randomized; PC, placebo-controlled; DBP, diastolic blood pressure; FA, folic acid; DHA, docosahexaenoic acid; RR, relative risk; OR, odds ratio; $\mathrm{Cl}$, confidence interval.

certain types of fish be consumed due to concerns about mercury contamination.

In addition, discussions have centered on the best source of DHA. The most common supplements are derived either from fish oil or microalgae. ${ }^{28}$ While both types of supplements have reported good safety and efficacy profiles, the microalgae-derived products have several advantages over the fish-derived products. First, supplements derived from microalgae are acceptable to vegetarians who do not consume fish. Second, mercury or polychlorinated biphenyl contamination of microalgae supplements has not been reported in the scientific literature, which is in contrast with what has been found in fish oil supplements. ${ }^{29}$ Third, overfishing is recognized as a prevalent problem around the globe, but products derived from microalgae do not contribute to this environmental burden. Furthermore, although algae is an important component of the marine life cycle, the algae used to produce supplements is generally grown in fermenters, so there is no impact on the environment. Fourth, no allergic reactions to microalgae supplements have been reported in the scientific literature, which is in contrast with fish oil supplements, which have been associated with adverse allergic reactions and the risk may be higher in those with fish allergies. ${ }^{30,31}$ Lastly, patients have reported a problem with a fishy taste significantly more often with fish oil than microalgae supplements. ${ }^{32}$

\section{Pregnancy-induced oxidative stress}

Pregnancy is undoubtedly associated with an increased susceptibility to oxidative stress. ${ }^{33}$ Oxidative stress results from the imbalance between oxygen free radicals and the essential antioxidants that maintain homeostasis. Free radicals are unstable and highly reactive, causing cell damage during the process of becoming stable through the 
acquisition of electrons from nucleic acids, lipids, proteins, and carbohydrates. ${ }^{34}$ While oxygen free radicals serve as key signaling molecules and lead to necessary pathological processes, an abundance of these free radicals in excess of available antioxidant-buffering capacity can cause adverse outcomes for the mother, the developing fetus, and the child after birth. ${ }^{33}$ The increased physiologic demands of pregnancy are associated with increased basal oxygen consumption, changes in energy substrate used by different organs, and production of free radicals that damage the endothelial lining cells of the maternal vasculature. ${ }^{33}$ Transitional metals, especially iron and cadmium, which are abundant in the placenta, are also involved in the production of free radicals. ${ }^{33,35}$ The transfer of iron to the placenta and fetus is enhanced by incremental increases in placental blood flow and transferrin receptors as pregnancy progresses. ${ }^{33}$ Cadmium is a common pollutant from a variety of sources, including tobacco smoke, and is easily detectable in meat, fish, and fruits due to high concentration in the soil and water supply. It accumulates over time in the blood and several organs, including the placenta. ${ }^{35}$ Pregnancy complications, such as preeclampsia, preterm labor, and intrauterine growth restriction, are all examples of conditions that can result from free radical damage. ${ }^{36}$ Antioxidants function by converting reactive oxygen species to water, thereby alleviating maternal and early fetal damage, allowing endothelial cells to heal. ${ }^{33,34}$ Therefore, it can be hypothesized that prenatal nutritional supplements that promote oxidative homeostasis may aid in preventing several maternal-fetal complications. However, to date, not all micronutrients contained within current prenatal supplements with antioxidant properties have been reported to be beneficial in reducing complications of pregnancy associated with oxidative stress.

\section{Prenatal obstetric complications correlated with oxidative stress}

Among the 875,000 women who experience one or more pregnancy complications every year, between $30 \%$ and $40 \%$ (about $4 \%-6 \%$ of total yearly pregnancies) are affected by preeclampsia, preterm labor, or preterm rupture, all complications that have the potential to affect both the mother and the fetus adversely. ${ }^{37-39}$

\section{Preeclampsia}

Preeclampsia is the second leading cause of maternal morbidity and mortality in the US, and is also associated with a significant increase in perinatal mortality. Infants born to affected mothers face a five-fold increase in mortality. ${ }^{40}$ Preeclampsia usually occurs after 20 weeks of gestation, and is characterized by hypertension and proteinuria. ${ }^{40}$ In addition, it is associated with diffuse endothelial activation and dysfunction as well as oxidative stress which occurs over several weeks or months, and is characterized by focal or segmental vasospasm, a proinflammatory state, and prothrombic properties. ${ }^{42}$ Subcellular mechanisms that participate in vasoconstriction, resulting from endothelial cell dysfunction, include decreased nitric oxide generation and excess free radicals. ${ }^{43}$ The severity of vascular endothelial dysfunction has been reported to have prognostic value for maternal hypertension, strokes, intrauterine growth restriction, and placental abruption. ${ }^{43,44}$ Clinically, there is no cure for preeclampsia, and it is usually treated by placental delivery following vaginal birth, cesarean section, or after abortion. ${ }^{45,46}$ If preeclampsia is not properly diagnosed, monitored, and treated, the condition can quickly progress to eclampsia, an acute and life-threatening complication characterized by the appearance of tonic-clonic seizures and/or coma. The clinical manifestations of this condition can appear any time from the second trimester through the postpartum period. ${ }^{47}$

While the pathogenesis of preeclampsia has not been completely elucidated, it is believed to be mediated by a generalized maternal inflammatory response that originates in the placenta, and is characterized by activation of vascular endothelial cells and maternal leukocytes. The pathogenesis of preeclampsia has been described as a two-stage process involving reduced placental perfusion, followed by the release of placental factors that trigger maternal vascular endothelial cell dysfunction. ${ }^{48}$ Presence of specific mediators of oxidative stress in the intervillus space, and subsequent transfer of those mediators to the maternal systemic circulation has been hypothesized as the link between the two stages, triggering the endothelial dysfunction. ${ }^{43,49}$ The increased rate of lipid peroxidation and decrease in antioxidants such as selenium, beta-carotene, and alpha-tocopherol observed in women with preeclampsia seem to support this hypothesis, although decreased antioxidants could be evidence of either an antioxidant deficiency or of excess free radical generation. ${ }^{44,50}$ Based on this evidence, antioxidants have been proposed for prevention and treatment of this condition. ${ }^{50}$

\section{Preterm labor and preterm rupture of membranes}

Spontaneous preterm birth is commonly defined as any delivery before 37 weeks' gestation. Infants are born preterm 
following spontaneous labor with intact membranes (about $45 \%$ of cases), preterm membrane rupture (about $30 \%$ ), and after labor induction or cesarean delivery for maternal or fetal indications (about 25\%). ${ }^{51,52}$ While these events are distinctively defined, the evidence indicates that the risk factors for their occurrence are similar. ${ }^{53}$ Since most fetal organs are not fully developed, the earlier the delivery prior to 37 weeks, the greater the risk for long-term newborn health complications. Premature infants born after 34 weeks of pregnancy tend to have less chance of complications than those born earlier. Infants born between 22 and 34 weeks of pregnancy have increased mortality and morbidity rates. $^{51,52}$ Two thirds of the perinatal mortality and half of long-term neurologic disabilities, including cerebral palsy, are associated with preterm birth. ${ }^{52}$ Obstetric triggers for preterm labor include premature rupture of membranes, uterine infections, multifetal pregnancy, or disorders that include preeclampsia, placental abnormalities, such as previa and abruption, and pyelonephritis, leading to an increase in medically indicated deliveries before 37 weeks' gestation. Preterm birth is very common in women who experience preterm premature rupture of membranes, but with intact membranes, pregnancy can be extended significantly in up to $50 \%$ of the cases. ${ }^{52}$

Several lines of evidence implicate oxidative stress in preterm labor. In a case-control study in 265 Korean women, oxidative stress-related gene interactions were associated with preterm delivery. ${ }^{54}$ Several studies utilizing urinary or plasma biomarkers for oxidative stress have yielded associations between oxidative stress, decreased serum antioxidant status, and shortened gestation duration. ${ }^{55-57}$ Oxidative stress has also been implicated in preterm rupture of membranes, in which increased generation of reactive oxygen species may arise from infection and inflammation, cigarette smoking, or vaginal bleeding and release of free iron. ${ }^{58}$ As with preeclampsia, the role of oxidative stress in preterm labor and preterm rupture of membranes suggests antioxidants may help to prevent these events. ${ }^{33,48}$

Preeclampsia, preterm labor, and preterm rupture of membranes have been associated with oxidative stress and increased levels of lipid peroxidation. Imbalances between lipid peroxides and antioxidants have been reported in preeclampsia, and may contribute to vascular endothelial cell damage ${ }^{50}$ Reduced perfusion of the placental tissue, in turn, may lead to the production of large amounts of oxygen-free radicals responsible for lipid peroxidation. Oxidative stress in high risk or preeclamptic patients is likely to be worsened by high levels of free radicals and low nutritional status.
Previous studies of plasma antioxidants in preeclampsia have primarily focused on single supplements, such as vitamin E, vitamin C, carotenoids, and thiols. Three large studies of combinations of vitamin $\mathrm{C}$ and vitamin $\mathrm{E}$ are summarized in Table 2. In a large study of 10,154 women, the combination of vitamin C $1000 \mathrm{mg}$ and vitamin E $400 \mathrm{IU}$ was started at 9-16 weeks' gestation and continued throughout pregnancy, and showed lack of efficacy in preventing the condition, despite consistent evidence for a state of oxidative stress. ${ }^{59}$ A second study conducted in Brazil treated 355 women at 12-19 weeks' gestation with vitamin C $1000 \mathrm{mg}$ and vitamin E $400 \mathrm{IU}$ or placebo $(\mathrm{n}=352) .{ }^{60}$ This study also failed to demonstrate any beneficial effect on reducing the rate of preeclampsia. ${ }^{60}$ The placebo-controlled VIP (Vitamin C and vitamin $\mathrm{E}$ In pregnant women at risk for Preeclampsia) trial of vitamin C $1000 \mathrm{mg}$ and vitamin E 400 IU administered daily from the second trimester of pregnancy until delivery in 2410 women yielded similar incidences of preeclampsia in the treatment and placebo groups, but a higher incidence of low birth weight babies among women who took antioxidants compared with controls. ${ }^{61}$ While a recent meta-analysis concluded that there is not enough evidence to support routine use of these antioxidants during pregnancy to reduce the risk of preeclampsia, ${ }^{62}$ the potential importance of oxidative stress in preeclampsia has led investigators to consider the use of other antioxidants, such as coenzyme Q10 and lycopene.

\section{Next generation antioxidants for prenatal nutrition Coenzyme QI0}

Coenzyme Q10 is an essential component of oxidative phosphorylation at the mitochondrial level. It also has potent antioxidant and membrane-stabilizing properties, ${ }^{62}$ and is postulated to be a modulator of gene expression and cell growth. ${ }^{63,64}$ As shown in Table $3,{ }^{65}$ coenzyme Q10 is found in a variety of food sources.

Given its antioxidant benefits, coenzyme Q10 has also been used as a dietary supplement in a number of countries, such as Japan and the US, as well as all across Europe, for more than 30 years. ${ }^{66}$ Data from both clinical and preclinical studies indicate that coenzyme Q10 has a safety profile appropriate for use as a dietary supplement, does not interfere with the biosynthesis of endogenous coenzyme Q9/coenzyme Q10, nor does it accumulate in plasma or tissues.$^{66}$ Three preclinical studies examined the genotoxicity of coenzyme Q10, with no genotoxic or mutagenic potential reported.$^{66}$ A preclinical trial in mice and rats to examine the potential effects of coenzyme Q10 on fetal and neonatal 
Table 3 Coenzyme $Q_{10}$ levels in food ${ }^{65}$

\begin{tabular}{|c|c|c|c|c|c|}
\hline Food & $\begin{array}{l}\text { Concentration } \\
(\mathrm{mg} / \mathrm{kg})\end{array}$ & Food & $\begin{array}{l}\text { Concentration } \\
(\mathrm{mg} / \mathrm{kg})\end{array}$ & Food & $\begin{array}{l}\text { Concentration } \\
(\mathrm{mg} / \mathrm{kg})\end{array}$ \\
\hline Beef & & Fish & & Oils & \\
\hline Beef heart & 113 & Sardines & $5-64$ & Soybean & 54-282 \\
\hline Beef liver & $39-50$ & Red flesh & $43-67$ & Olive & $4-160$ \\
\hline Beef & $16-40$ & White flesh & $11-16$ & Rapeseed & $64-73$ \\
\hline Pork & $13-45$ & Salmon & $4-8$ & Sunflower & $4-15$ \\
\hline Chicken & $8-25$ & Tuna & 5 & & \\
\hline Nuts & & Vegetables & & Fruit & \\
\hline Peanuts & 27 & Parsley & $8-26$ & Avocado & 10 \\
\hline Walnuts & 19 & Broccoli & $6-9$ & Blackcurrant & 3 \\
\hline Pistachio & 20 & Spinach & $1-10$ & Orange & $1-2$ \\
\hline Hazelnuts & 17 & Cauliflower & $2-7$ & Strawberry & 1 \\
\hline Almond & $5-14$ & Cabbage & $2-5$ & Apple & 1 \\
\hline Sesame seed & $18-23$ & & & Grapefruit & I \\
\hline
\end{tabular}

development found no deleterious effects on the dams, the progress of pregnancy, or incidence of abnormalities, and no findings of postnatal toxicity. ${ }^{66}$ No teratogenic studies of coenzyme Q10 in human pregnancy have been reported to our knowledge. In studies performed in healthy humans and those with chronic illnesses such as heart failure, Huntington's disease, and Parkinson's disease, no serious adverse effects associated with coenzyme Q10 were observed. ${ }^{6}$ Doses employed in these studies were as high as $3000 \mathrm{mg} /$ day administered for as long as eight months. A study by Teran et al in 2009 used coenzyme Q10 supplementation at $200 \mathrm{mg} /$ day in pregnant women for 20 weeks and reported no differences in birth weight between those who received coenzyme Q10 or placebo (2981 g versus 2938 g, respectively). There was no perinatal mortality, and the duration of pregnancy was equivalent for both groups. ${ }^{67}$ However, the dosage used in that study was lower than the acceptable daily intake of coenzyme Q10, which has been calculated at $12 \mathrm{mg} / \mathrm{kg} / \mathrm{day}$, which for a $60 \mathrm{~kg}$ person is $720 \mathrm{mg} /$ day. $^{58}$ The Council for Responsible Nutrition has determined that $1200 \mathrm{mg} /$ day is the "observed safe level" of coenzyme Q10. Although no studies of the effects of nutritional supplements on coenzyme Q10 concentrations in breast milk have been performed, coenzyme Q10, as a naturally occurring compound, has been found in human breast milk. ${ }^{68}$ However, in one study, higher concentrations of coenzyme Q10 were found in the bloodstream of nursing mothers than in breast milk. ${ }^{68}$ The implications of these findings are unknown. There are no studies evaluating the safety of coenzyme Q10 in nursing infants.

Evidence of the cellular role of coenzyme Q10 suggests that this molecule may have a role in preventing preeclampsia in pregnant women. For example, one study showed that levels of coenzyme Q10 in preeclamptic women were half those in women without preeclampsia, which has been confirmed by cohort studies. ${ }^{64,69,70}$ The effect of coenzyme Q10 supplementation in pregnant women at increased risk of preeclampsia was recently assessed in a randomized, doubleblind, placebo-controlled trial. Two hundred and thirty-five women were assigned to receive $200 \mathrm{mg}$ of coenzyme Q10 or placebo daily from 20 weeks of pregnancy until delivery (Table 2). The rate of preeclampsia in the placebo group was significantly higher than that in the coenzyme Q10 group (25.6\% versus $14.4 \%, P=0.035$ ), indicating that supplementation with coenzyme Q10 reduces the risk of developing preeclampsia in women at risk for this condition. Mild gastrointestinal symptoms were the most common adverse effects, but the difference was not significant between the groups $(1.3 \%$ in the coenzyme Q10 group experienced gastrointestinal symptoms versus $1.5 \%$ for the placebo group, $P=0.84){ }^{67}$

A recent longitudinal study to assess the relationship between maternal serum coenzyme Q10 levels and maternal body weight gain, fat mass gain, and infant birth weight was conducted in 50 healthy pregnant women. Maternal serum coenzyme Q10 levels were positively correlated with maternal weight gain $(P<0.05)$ and fat mass gain $(P<0.05)$, as well as positively correlated with fetal growth $(P<0.05){ }^{71}$ This study did not investigate differences in dietary intake between the groups.

Coenzyme Q10 was found to increase levels of extracellular superoxide dismutase, a major antioxidant enzyme system of the vessel wall that has been reported to lead to endothelium-dependent dilation of conduit arteries. ${ }^{72,73}$ The ability of oral coenzyme Q10 supplementation (100 mg three times daily) to improve extracellular superoxide dismutase 
activity and endothelium-dependent vasodilation in patients with coronary artery disease was investigated in a recent randomized trial. Both extracellular superoxide dismutase and endothelium-dependent relaxation, as well as peak $\mathrm{VO}_{2}$ and $\mathrm{O}_{2}$ pulse increases in the coenzyme Q10-treated group, were statistically greater versus the variations in the placebo group. Improvements induced by coenzyme Q10 supplementation were particularly remarkable in patients with low initial endothelium-bound extracellular superoxide dismutase and thus more prone to oxidative stress. Together, these results suggest that the improvements in endothelium-dependent relaxation and endothelium-bound extracellular superoxide dismutase activity might be related to the ability of coenzyme Q10 to enhance endothelial functionality by counteracting nitric oxide oxidation. ${ }^{73}$

\section{Lycopene}

Deficiency of lycopene, a carotenoid, has been associated with preterm labor and intrauterine growth restriction. ${ }^{74,75}$ Lycopene is a carotenoid present in human serum and skin as well as in the liver, adrenal glands, lungs, prostate, and colon. This micronutrient is believed to possess antioxidant and antiproliferative properties. ${ }^{76,77}$ The evidence suggests that lack of lycopene is associated with cancers of the digestive tract, cervical intraepithelial neoplasms, breast cancer, skin cancer, bladder cancer, prostate cancer, and cardiovascular disease. ${ }^{78-85}$ A prospective, randomized, controlled study showed that, in primigravid women in the second trimester, administration of oral lycopene $2 \mathrm{mg}$ twice daily reduced the rate of preeclampsia compared with placebo $(8.6 \%$ in the lycopene group versus $17.7 \%$ in the placebo group, $P=0.043$, Table 2). ${ }^{74}$ The incidence of intrauterine growth restriction was also found to be significantly lower in the lycopene group (12\% in the lycopene group versus $23.7 \%$ in the placebo group, $P=0.033$ ). A prospective, multicenter cohort study of 5337 women examined frozen plasma samples from spontaneous preterm births $(\mathrm{n}=207)$ and term controls $(n=443)$ for carotenoids, retinol, tocopherols, and long-chain fatty acids (Table 2 ).${ }^{75}$ High plasma concentrations of lycopene were associated with a reduced risk of spontaneous preterm birth, with evidence of dose-response effects across quartiles. Together, these results suggest a potential role for lycopene in reducing the incidence of preeclampsia, preterm birth, and subsequent intrauterine growth restriction in pregnant women. ${ }^{75}$ However, a recent study conducted by Banerjee et al, utilizing a lycopene dose of $2 \mathrm{mg}$ daily in primigravidas beginning on average at week 15.7, showed no difference in the rate of preeclampsia between the lycopene and placebo groups ${ }^{86}$ Furthermore, this study reported a significantly higher incidence of adverse events, such as preterm labor and low birthweight, with lycopene supplementation. The investigators noted that a dose of $2 \mathrm{mg}$ daily may not be an optimal dose to show a statistical difference compared with placebo, and that the study population may have been too low-risk for discerning complication rates between the groups. Additional studies of lycopene are warranted in this area.

Lycopene is a naturally occurring compound, which is found in high concentrations in a variety of foods, including tomatoes. However, little data are available on the teratogenicity of lycopene or its safety during breastfeeding. In a study of rats and rabbits administered high doses of lycopene during gestation, no effects on body weight, necropsy findings, fetal development, or skeletal morphology were observed in the offspring. ${ }^{87}$ Another study has reported that tomato consumption increases lycopene isomer concentrations in both the breast milk and plasma of lactating women without complications. ${ }^{88}$ In this study, the concentration of lycopene in breast milk was one tenth that of the serum concentration. Lycopene is designated "Generally Recognized as Safe" by the US Food and Drug Administration. However, no specific studies are available to address its safety or lack thereof in breastfeeding, and there are no studies evaluating the safety of lycopene in nursing infants.

While the overall number of published clinical trials using either coenzyme Q10 or lycopene in pregnant women is currently limited, the results to date, combined with the Generally Recognized as Safe designation of these ingredients by the Food and Drug Administration, provide a foundation for future research into their utility for preventing pregnancy-related complications reported to result from oxidative stress.

Despite their potential role in minimizing preeclampsia, rupture of membranes, and preterm labor, to our knowledge, coenzyme Q10 and lycopene are only included in one commercial prescription prenatal nutritional supplement.

\section{Conclusion}

Considerable clinical and therapeutic evidence exists to support the need for nutritional supplementation during pregnancy for the benefits conferred to both mother and fetus. Therapeutic knowledge, clinical research, and technological advancements have had a significant impact on the prenatal nutrition market, from the initial focus on high calcium loads and iron and folic acid supplementation in the 1980s and 1990s, to the inclusion of DHA, smaller tablet 
size, and improved taste in this century. As the 21 st century progresses, we should continue to focus on the importance of precise amounts of micronutrient supplementation and perhaps consider the next stage of antioxidant therapy aimed at minimizing oxidative stress in the expectant mother.

\section{Disclosure}

None of the authors involved in this manuscript have received any remuneration for the concept, research, or writing of this manuscript.

\section{References}

1. Scholl TO. Maternal nutrition before and during pregnancy. Nestle Nutr Workshop Ser Pediatr Program. 2008;61:79-89.

2. Kaiser LL, Allen L. American Dietetic Association. Position of the American Dietetic Association: Nutrition and lifestyle for a healthy pregnancy outcome. J Am Diet Assoc. 2002;102:1479-1490.

3. The American College of Obstetricians and Gynecologists. Nutrition During Pregnancy. ACOG pamphlet number AP001. Available from: http://www.acog.org/publications/patient_education/bp001.cfm. Accessed January 25, 2011.

4. Kontic-Vucinic O, Sulovic N, Radunovic N. Micronutrients in women's reproductive health: I. Vitamins. Int J Fertil Womens Med. 2006;51: $106-115$.

5. Picciano MF, McGuire MK. Use of dietary supplements by pregnant and lactating women in North America. Am J Clin Nutr. 2009;89 Suppl:663S-667S.

6. Wilson RD, Johnson JA, Wyatt P, et al. Pre-conceptional vitamin/ folic acid supplementation 2007: The use of folic acid in combination with a multivitamin supplement for the prevention of neural tube defects and other congenital anomalies. J Obstet Gynaecol Can. 2007;29:1003-1006.

7. Goh YI, Bollano E, Einarson TR, Koren G. Prenatal multivitamin supplementation and rates of congenital anomalies: A meta-analysis. J Obstet Gynaecol Can. 2006;28:680-689.

8. Daly S, Mills JL, Molloy AM, et al. Minimum effective dose of folic acid for food fortification to prevent neural-tube defects. Lancet. 1997;350:1666-1669.

9. Wald NJ, Law MR, Morris JK, Wald DS. Quantifying the effect of folic acid. Lancet. 2001;358:2069-2073.

10. National Institutes of Health: Office of Dietary Supplements. Dietary supplement fact sheet: Folate. Available from: http://dietarysupplements.info.nih.gov/factsheets/folate.asp. Accessed January 25, 2011.

11. Reynolds EH. Mental effects of anticonvulsants and folic acid metabolism. Brain. 1968;91:197-214.

12. Lamers Y, Prinz-Langenohl R, Brämswig S, Pietrzik K. Red blood cell folate concentrations increase more after supplementation with [6S]-5-methyltetrahydrofolate than with folic acid in women of childbearing age. Am J Clin Nutr. 2006;84:156-161.

13. Daly LE, Kirke PN, Molloy A, Weir DG, Scott JM. Folate levels and neural tube defects. Implications for prevention. JAMA. 1995;274: $1698-1702$.

14. Venn BJ, Green TJ, Moser R, McKenzie JE, Skeaff CM, Mann J. Increases in blood folate indices are similar in women of childbearing age supplemented with [6S]-5-methyltetrahydrofolate and folic acid. J Nutr. 2002;132:335-5.

15. American Academy of Pediatrics Committee on Genetics. Folic acid for the prevention of neural tube defects. Pediatrics. 1999;104: 325-327.

16. Carlson SE. Docosahexaenoic acid supplementation in pregnancy and lactation. Am J Clin Nutr. 2009;89 Suppl:678S-684S.
17. Jensen CL, Voigt RG, Llorente AM, et al. Effects of early maternal docosahexaenoic acid intake on neuropsychological status and visual acuity at five years of age of breast-fed term infants. J Pediatr. 2010;157:900-905.

18. Hadders-Algra M. Prenatal long-chain polyunsaturated fatty acid status: The importance of a balanced intake of docosahexaenoic acid and arachidonic acid. $J$ Perinat Med. 2008;36:101-109.

19. Makrides M, Gibson RA, McPhee AJ, et al. Effect of DHA supplementation during pregnancy on maternal depression and neurodevelopment of young children. JAMA. 2010;304:1675-1683.

20. van Goor SA, Janneke Dijck-Brouwer DA, Ershch JJ, Schaafsma A, Hadders-Algra M. The influence of supplemental docosahexaenoic and arachidonic acids during pregnancy and lactation on neurodevelopment at eighteen months. Prostaglandins Leukot Essent Fatty Acids. 2011;84:139-146.

21. Stein AD, Wang M, Martorell R, et al. Growth to age 18 months following prenatal supplementation with docosahexaenoic acid differs by maternal gravidity in Mexico. J Nutr. 2011;141:316-320.

22. Ramakrishnan U, Stein AD, Parra-Cabrera S, et al. Effects of docosahexaenoic acid supplementation during pregnancy on gestational age and size at birth: Randomized, double-blind, placebo-controlled trial in Mexico. Food Nutr Bull. 2010;31 Suppl 2:S108-S116.

23. Simopoulos AP, Leaf A, Salem N Jr. Workshop on the essentiality of and recommended dietary intakes (RDI) for omega- 6 and omega-3 fatty acids. April 7-9, 1999; Bethesda, MD. Available from: http:// www.issfal.org/index.php/archive-mainmenu-14/adequate-intakesmainmenu-50. Accessed April 14, 2011.

24. Koletzko B, Lien E, Agostoni C, et al. The roles of long-chain polyunsaturated fatty acids in pregnancy, lactation and infancy: Review of current knowledge and consensus recommendations. J Perinat Med. 2008;36:5-14.

25. Koletzko B, Cetin I, Brenna JT, et al. Dietary fat intakes for pregnant and lactating women. Br J Nutr. 2007;98:873-877.

26. Arterburn LM, Oken HA, Bailey Hall E, et al. Algal-oil capsules and cooked salmon: Nutritionally equivalent sources of docosahexaenoic acid. J Am Diet Assoc. 2008;108:1204-1209.

27. Visioli F, Risé P, Barassi MC, Marangoni F, Galli C. Dietary intake of fish vs formulations leads to higher plasma concentrations of n-3 fatty acids. Lipids. 2003;38:415-418.

28. Cannon D. From fish oil to microalgae oil. A win-win shift for humans and our habitat. Explore. 2009;5:299-303.

29. Doughman SD, Krupanidhi S, Sanjeevi CB. Omega-3 fatty acids for nutrition and medicine: Considering microalgae oil as a vegetarian source of EPA and DHA. Curr Diabetes Rev. 2007;3:198-203.

30. Brigham and Women's Hospital. Fish oil, omega-3 fatty acids. Available from: http://healthlibrary.brighamandwomens.org/Library/Drug Reference/26,2722?PrinterFriend. Accessed January 25, 2011.

31. MedlinePlus. Fish oil. Available from: http://www.nlm.nih.gov/ medlineplus/druginfo/natural/993.html. Accessed January 25, 2011.

32. Schwellenbach LJ, Olson KL, McConnell KJ, et al. The triglyceridelowering effects of a modest dose of docosahexaenoic acid alone versus in combination with low dose eicosapentaenoic acid in patients with coronary artery disease and elevated triglycerides. J Am Coll Nutr. 2006;25:480-485.

33. Casanueva E, Viteri FE. Iron and oxidative stress in pregnancy. J Nutr. 2003;(5 Suppl 2)133:1700S-1708S.

34. Agarwal A, Gupta S, Sharma RK. Role of oxidative stress in female reproduction. Reprod Biol Endocrinol. 2005;3:28.

35. Henson MC, Chedrese PJ. Endocrine disruption by cadmium, a common environmental toxicant with paradoxical effects on reproduction. Exp Biol Med. 2004;229:383-392.

36. Buhimschi IA, Buhimschi CS, Pupkin M, Weiner CP. Beneficial impact of term labor: Nonenzymatic antioxidant reserve in the human fetus. Am J Obstet Gynecol. 2003;189:181-188.

37. American Pregnancy Association, Statistics. Available from: http://www. americanpregnancy.org/main/statistics.html. Accessed January 25, 2011.

38. Newton ER. Preterm labor, preterm premature rupture of membranes, and chorioamnionitis. Clin Perinatol. 2005;32:571-600. 
39. Furman B, Shoham-Vardi I, Bashiri A, Erez O, Mazor M. Clinical significance and outcome of preterm prelabor rupture of membranes: Population-based study. Eur J Obstet Gynecol Reprod Biol. 2000;92:209-216.

40. Hawfield A, Freedman BI. Pre-eclampsia: The pivotal role of the placenta in its pathophysiology and markers for early detection. Ther $A d v$ Cardiovasc Dis. 2009;3:65-73.

41. National Heart and Lung Blood Institute. Working Group Report on High Blood Pressure in Pregnancy. Available from: http://www.nhlbi. nih.gov/guidelines/archives/hbp_preg/hbp_preg_archive.pdf. Accessed on March 17, 2009.

42. Sibai BM. Diagnosis and management of gestational hypertension and preeclampsia. Obstet Gynecol. 2003;102:181-192.

43. Endemann DH, Schiffrin EL. Endothelial dysfunction. J Am Soc Nephrol. 2004;15:1983-1992.

44. Myatt L, Webster RP. Vascular biology of preeclampsia. J Thromb Haemost. 2009; 7:375-384.

45. Sibai B, Dekker G, Kupferminc M. Pre-eclampsia. Lancet. 2005;365: 785-799.

46. Mutter WP, Karumanchi SA. Molecular mechanisms of preeclampsia. Microvasc Res. 2008;75:1-8.

47. MacKay AP, Berg CJ, Atrash HK. Pregnancy-related mortality from preeclampsia and eclampsia. Obstet Gynecol. 2001;97:533-538.

48. Roberts JM, Hubel CA. Is oxidative stress the link in the two-stage model of pre-eclampsia? Lancet. 1999;354:788-789.

49. Ouyang YQ, Li SJ, Zhang Q, Cai HB, Chen HP. Interactions between inflammatory and oxidative stress in preeclampsia. Hypertens Pregnancy. 2009;28:56-62.

50. Roberts JM, Speer P. Antioxidant therapy to prevent preeclampsia. Semin Nephrol. 2004;24:557-564.

51. Goldenberg RL, Culhane JF, Iams JD, Romero R. Epidemiology and causes of preterm birth. Lancet. 2008;371:75-84.

52. Robertson PA, Sniderman SH, Laros RK Jr, et al. Neonatal morbidity according to gestational age and birth weight from five tertiary care centers in the United States, 1983 through 1986. Am J Obstet Gynecol. 1992;166:1629-1645.

53. Denney JM, Culhane JL, Goldenberg RL. Prevention of preterm birth. Womens Health (Lond Engl). 2008;4:625-638.

54. Juh YJ, Kim YJ, Park H, Park EA, Ha EH. Oxidative stress-related gene interactions with preterm delivery in Korean women. Am JObstet Gynecol. 2008;198;541:e1-e7.

55. Peter Stein T, Scholl TO, Schluter MD, et al. Oxidative stress early in pregnancy and pregnancy outcome. Free Radic Res. 2008;42: 841-848.

56. Cinkaya A, Keskin HL, Buyukkagnici U, et al. Maternal plasma total antioxidant status in preterm labor. J Obstet Gynaecol Res. 2010;36: 1185-1188.

57. Joshi SR, Mehendale SS, Dangat KD, Kilari AS, Yadav HR, Taralekar VS. High maternal plasma antioxidant concentrations associated with preterm delivery. Ann Nutr Metab. 2008;53:276-282.

58. Burton GJ, Jauniaux E. Oxidative stress. Best Pract Res Clin Obstet Gynaecol. December 2, 2010. [Epub ahead of print].

59. Roberts JM, Myatt L, Spong CY, et al. Vitamins C and E to prevent complications of pregnancy-associated hypertension. $N$ Engl J Med. 2010;362:1282-1291.

60. Spinnato JA 2nd, Freire S, Pinto E, et al. Antioxidant therapy to prevent preeclampsia: A randomized controlled trial. Obstet Gynecol. 2007;110:1311-1318.

61. Poston L, Briley AL, Seed PT, Kelly FJ, Shennan AH. Vitamins in Pre-eclampsia VIP Trial Consortium. Vitamin C and vitamin E in pregnant women at risk for pre-eclampsia (VIP trial): Randomized placebo-controlled trial. Lancet. 2006;367:1145-1154.

62. Rahimi R, Nikfar S, Rezaie A, Abdollahi M. A meta-analysis on the efficacy and safety of combined vitamin $\mathrm{C}$ and $\mathrm{E}$ supplementation in preeclamptic women. Hypertens Pregnancy. 2009;28:417-434.

63. Crane FL, Navas P. The diversity of coenzyme Q function. Mol Aspects Med. 1997;18 Suppl:S1-S6.
64. Teran E, Racines-Orbe M, Vivero S, Escudero C, Molina G, Calle A. Preeclampsia is associated with a decrease in plasma coenzyme Q10 levels. Free Radic Biol Med. 2003;35:1453-1456.

65. Pravst I, Zmitek K, Zmitek J. Coenzyme Q10 contents in foods and fortification strategies. Crit Rev Food Sci Nutr. 2010;50:269-280.

66. Hidaka T, Fujii K, Funahashi I, Fukutomi N, Hosoe K. Safety assessment of coenzyme Q10 (CoQ10). Biofactors. 2008;32:199-208.

67. Teran E, Hernandez I, Nieto B, Tavara R, Ocampo JE, Calle A. Coenzyme Q10 supplementation during pregnancy reduces the risk of pre-eclampsia. Int J Gynaecol Obstet. 2009;105:43-45.

68. Quiles JL, Ochoa JJ, Ramirez-Tortosa MC, et al. Coenzyme Q concentration and total antioxidant properties of human milk at different stages of lactation in mothers of preterm and full-term infants. Free Radic Res. 2006;40:199-206.

69. Teran E, Vivero S, Racines-Orbe M, et al. Coenzyme Q10 is increased in placenta and cord blood during preeclampsia. Biofactors. 2005;25: 153-158.

70. Palan PR, Shaban DW, Martino T, Mikhail MS. Lipid-soluble antioxidants and pregnancy: Maternal serum levels of coenzyme Q10, alpha-tocopherol and gamma-tocopherol in preeclampsia and normal pregnancy. Gynecol Obstet Invest. 2004;58:8-13.

71. Haruna M, Matsuzaki M, Ota E, et al. Positive correlation between maternal serum coenzyme Q10 levels and infant birth weight. Biofactors. 2010;36:312-318.

72. Landmesser U, Merten R, Spiekermann S, Büttner K, Drexler H, Hornig B. Vascular extracellular superoxide dismutase activity in patients with coronary artery disease: Relation to endothelium-dependent vasodilation. Circulation. 2000;101:2264-2270.

73. Tiano L, Belardinelli R, Carnevali P, Principi F, Seddaiu G, Littarru GP. Effect of coenzyme Q10 administration on endothelial function and extracellular superoxide dismutase in patients with ischaemic heart disease: A double-blind, randomized controlled study. Eur Heart J. 2007;28:2249-2255.

74. Sharma JB, Kumar A, Kumar A, et al. Effect of lycopene on preeclampsia and intra-uterine growth retardation in primigravidas. Int J Gynaecol Obstet. 2003;81:257-262.

75. Kramer MS, Kahn SR, Platt RW, et al. Antioxidant vitamins, long-chain fatty acids, and spontaneous preterm birth. Epidemiology. 2009;20: 707-713.

76. Clinton SK. Lycopene: Chemistry, biology, and implications for human health and disease. Nutr Rev. 1998;56:35-51.

77. Di Mascio P, Kaiser S, Sies H. Lycopene as the most efficient biological carotenoid singlet oxygen quencher. Arch Biochem Biophys. 1989; 274:532-538.

78. Tsugane S, Tsuda M, Gey F, Watanabe S. Cross-sectional study with multiple measurements of biological markers for assessing stomach cancer risks at the population level. Environ Health Perspect. 1992; 98:207-210.

79. Van Eenwyck J, Davis FG, Bowen PE. Dietary and serum carotenoids and cervical intraepithelial neoplasia. Int J Cancer. 1991;48:34-38.

80. Garland M, Willett WC, Manson JE, Hunter DJ. Antioxidant micronutrients and breast cancer. J Am Coll Nutr. 1993;12:400-411.

81. Ribayo-Mercado JD, Garmyn M, Gilchrest BA, Russell RM. Skin lycopene is destroyed preferentially over beta-carotene during ultraviolet irradiation in humans. J Nutr. 1995;125:1854-1859.

82. Helzlsouer KJ, Comstock GW, Morris JS. Selenium, lycopene, alfatocopherol, beta-carotene, retinol, and subsequent bladder cancer. Cancer Res. 1989;49:6144-6148.

83. Giovannucci E, Ascherio A, Rimm EB, Stampfer MJ, Colditz GA, Willett WC. Intake of carotenoids and retinol in relation to risk of prostate cancer. J Natl Cancer Inst. 1995;87:1767-1776.

84. Frei B. Cardiovascular disease and nutrient antioxidants: Role of lowdensity lipoprotein oxidation. Crit Rev Food Sci Nutr. 1995;35(1-2): 83-98.

85. Erdman JW Jr, Ford NA, Lindshield BL. Are the health attributes of lycopene related to its antioxidant function? Arch Biochem Biophys. 2009;483:229-235. 
86. Banerjee S, Jeyaseelan S, Guleria R. Trial of lycopene to prevent preeclampsia in healthy primigravidas: Results show some adverse effects. J Obstet Gynecol. 2009;35(3):477-482.

87. Trumbo PR. Are there adverse effects of lycopene exposure? J Nutr. 2005; 135:2060S-2061S.

88. Alien CM, Smith AM, Clinton SK, Schwartz SJ. Tomato consumption increases lycopene isomer concentrations in breast milk and plasma of lactating women. J Am Diet Assoc. 2002;102:1257-1262.

89. PreQue ${ }^{\mathrm{TM}} 10$ [Package insert]. Ashland, VA: Atley Pharmaceuticals Inc; 2009.

90. OB Complete 400 [Package insert]. Sayreville, NJ: Vertical Pharmaceuticals Inc; 2009.

91. PreNexa Capsules [Package insert]. Maple Grove, MN: Upsher-Smith Laboratories Inc; 2008.

92. Prenate DHA [Package insert]. Atlanta, GA: Sciele Pharma Inc; 2008.

93. Vitafol-OB + DHA Caplets [Package insert]. Available at: http:// www.everettlabs.com/ever2/vitafol_ob_dha.asp. Accessed February 7, 2011 .
94. CitraNatal Assure [Package insert]. San Antonio, TX: Mission Pharmacal; 2009.

95. Gesticare DHA [Package insert]. Dublin, Ireland: Azur Pharma Inc; 2001.

96. OB Complete ${ }^{\mathrm{TM}}$ One [Package insert]. Sayreville, NJ: Vertical Pharmaceuticals Inc; 2010.

97. Prenate Essential ${ }^{\mathrm{TM}}$ [Package insert]. Atlanta, GA: Shionogi Pharma Inc; 2010.

98. CitraNatal ${ }^{\circledR}$ Harmony $^{\mathrm{TM}}$ [Package insert]. San Antonio, TX: Mission Pharmacal; 2010.

99. PreferaOB ONETM [Package insert]. Marietta, GA: Alaven Pharmaceuticals; 2010.

100. NeevoDHA ${ }^{\circledR}$ [Package insert]. Covington, LA: Pamlab; 2009.

101. Concept DHA ${ }^{\mathrm{TM}}$ [Package insert]. Decatur, GA: US Pharmaceutical Corp; 2010.

102. Minnesota Department of Health. Bayley Scales of Infant and Toddler Development. (BAYLEY-III). 3rd ed. Available from: www. pearsonassessments.com/HAIWEB/Cultures/en-us/Productdetail. htm?Pid=015-8027-23X. Accessed May 4, 2011.

\section{Publish your work in this journal}

Research and Reports in Neonatology is an international, peer-reviewed, open access journal publishing original research, reports, editorials, reviews and commentaries on neonatal health. The manuscript management system is completely online and includes a very quick and fair peer-review system. Visit http://www.dovepress.com/testimonials.php to read real quotes from published authors. 